\title{
The Effect of Self-Esteem on Leadership Orientation: A Study on Students of Sports Management Department
}

\author{
Ilker Gunel \\ Usak University, Faculty of Sport Science, Turkey. \\ Email: ilker.gunel@usak.edu.tr Tel: +905072624357
}

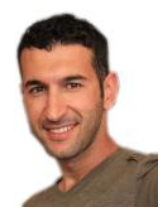

\begin{abstract}
In this study, which aims to examine the effect of self-esteem levels of students who receive sports management education on their leadership orientation, the population of this study, in which the related screening method is used among quantitative research designs, consists of students studying at the Sports Management departments of the Sports Sciences Faculties of the universities in the Central Anatolia Region. The sample of the study (female $=184$, male $=131$ ) consists of 315 students of sports management department, which was reached using the convenience sampling method, and a 95\% confidence interval has been used with an error margin of $5 \%$. Data from the participants were collected with Self-Esteem Scale and Leadership Orientation Scale. Since the data has normal distribution, parametric tests have been used: correlation to measure the relationship between two variables, and regression analysis to measure the effect of the independent variable on the dependent variable. A significant positive relationship was found with the self-esteem levels of the students and their leadership orientation in general and in sub-dimensions of task-oriented and relationship-oriented. In addition, self-esteem levels were found to have a significant effect on students' leadership orientation in general and in taskoriented and relationship-oriented sub-dimensions. As a result, it was found that students' selfesteem levels and leadership orientation levels are high, and as their self-esteem levels increase, their leadership orientation in general and in task-oriented and relationship-orientation subdimensions also increase.
\end{abstract}

Keywords: Self-Esteem, Leadership orientation, Sports management department, Faculty of sport science, Mission-oriented.

Citation | Illker Gunel (2021). The Effect of Self-Esteem on Leadership Orientation: A Study on Students of Sports Management Department. Asian Journal of Education and Training, 7(1): 91-95. History:

Received: 15 January 2021

Revised: 17 February 2021

Accepted: 19 March 2021

Published: 13 April 2021

Licensed: This work is licensed under a Creative Commons

Attribution 3.0 License $(\mathrm{coc})$ Ey

Publisher: Asian Online Journal Publishing Group
Funding: This study received no specific financial support

Competing Interests: The author declares that there are no conflicts of interests regarding the publication of this paper.

Transparency: The author confirms that the manuscript is an honest, accurate, and transparent account of the study was reported; that no vital features of the study have been omitted; and that any discrepancies from the study as planned have been explained.

Ethical: This study follows all ethical practices during writing.

\section{Contents}

1. Introduction

2. Method. 92

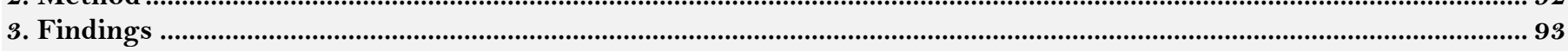

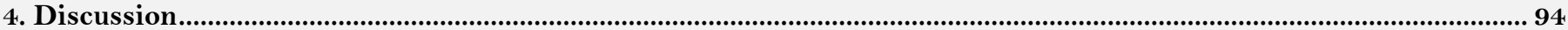

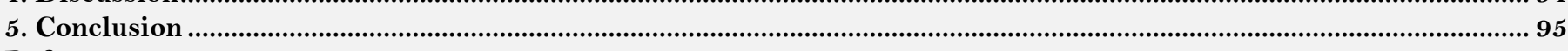

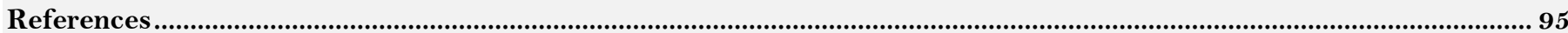




\section{Contribution of this paper to the literature}

The concept of self-esteem has been examined in many different ways in the literature. However, I think it will contribute to the literature in this respect since there are very few studies in terms of its effect on students' leadership tendencies.

\section{Introduction}

Today, it is known that the limitations that students experience in the face of their efforts to achieve goals such as anxiety about finding a job, financial expectations, desire to achieve a certain status in the future, and to live a comfortable life have a significant effect on their life standards. It is considered that self-esteem is one of the basic elements that individuals should have in order to have a happy life and to have a certain meaning in their lives. Studies on the concept of self-esteem by James (1892) and Cooley (1902) in the literature are known as the first scientific research that deeply influenced and guided existing self-esteem studies. Self-esteem can be defined as a feeling of worthiness and competence, expressing emotional reactions about the characteristics of the individual, the interactions of the person with the environment, the sense of self-acceptance of the individual and self-esteem towards themselves (Burger, 2006; Kernis, 2003; Morganett, 2005; Woolfolk \& Shaughnessy, 2004). In this context, self-esteem is realized through the balance between goals and achievements of individuals (James, 1892). Researchers think that this balance can be achieved by increasing the success factor or decreasing the goals (Coopersmith, 1981 ). Self-esteem has two important bases. The first of these is the individual's own experiences of success or failure from different areas, and the second is the feedback received from others who are important role models for individuals (Orth \& Robins, 2014). Individuals with high self-esteem have a determined, clear, and noncontradictory attitude towards themselves. Therefore, individuals with self-esteem have positive characteristics such as being self-confident, success-oriented, not giving up in the face of difficulties, and self-love. Individuals with low self-esteem, on the other hand, have inconsistent and mixed self-conceptions, underestimate their own abilities, and are not success-oriented or confident (Burger, 2006; Plummer, 2005). Factors such as family, social environment, and gender affect individuals' self-esteem (Çiçekler \& Pirpir, 2015; Yörükoğlu, 2000). In many studies, it has been found that the self-esteem levels of men are higher compared to women (Sayar, 2003). The concept of leadership has attracted the attention of many research organizations in various research disciplines due to its importance for individuals, professions, and different institutions and organizations (Geva \& Torpey, 2008; Harris, 2009). There are different views about the concept of leadership in the literature. While some sources state leadership as an innate characteristic, some sources state it as a quality that individuals can acquire and develop later (Harry, 2002). Leaders are individuals who are integrated around the ideas and principles internalized by organizations in the working environment, who are competent, take responsibilities, think that the assigned tasks are achievable, and understand the importance of empathy for personal development (Amanchukwu, Stanley, \& Ololube, 2015; Imbroda-Ortiz, Castillo-Rodríguez, \& Minguet, 2015; Topaloğlu \& Avcl, 2008). The concept of leadership orientation is the specific behavior of the leader while directing and managing the activities of the members of the organization to the established goals (House \& Aditya, 1997). In these leader-specific behaviors, leaders can provide employees with up-to-date thoughts and ideas, set specific goals to achieve, choose to support or prevent innovative initiatives from their employees (Correa, Morales, \& Pozo, 2005). In this context, leadership orientation should be in a certain harmony with the organizational atmosphere and organizational hierarchy in order to be effective and efficient (Suar, Tewari, \& Chaturbedi, 2006). In the literature, there are many factors that affect leadership orientation. For example, Mason, Mason, and Mathews (2016) found that self-esteem is quite effective on leadership orientation and that individuals with high self-esteem also have high leadership orientations. According to the results of the study, it was found that women with high self-esteem have a higher leadership understanding compared to men. One of the factors that affect leadership orientation is the concept of self-esteem, which we also discuss in our study. In the literature, it is considered that studies on whether the self-esteem levels of students studying in the department of sports management have an effect on the development of students' management/leadership qualities or their tendencies towards leadership are quite limited. In this respect, it is considered that our study will contribute to closing this gap in the literature. The hypotheses of this study, which aims to examine the effect of self-esteem levels of students studying in the department of sports management on leadership orientations, are listed as follows.

$H_{1}$ : There is a significant positive relationship between the Self-Esteem Levels of the students and their Leadership Orientation.

$H_{2:}$ Students' Self-Esteem Levels have a significant effect on Leadership Orientation.

\section{Method}

\subsection{Participant}

In this study, which aims to examine the effect of self-esteem of students studying at sports management departments at the Faculty of Sports Sciences on leadership orientation, correlational survey method, which is one of the quantitative research methods and examines the relationship between two continuous variables, has been used that (Gürbüz \& Şahin, 2018). The population of the study consists of students studying at the Sports Management Department of the Sports Sciences Faculties at various universities that provide sports management education in the Central Anatolia Region. The sample of the study (female $=184$, male $=131$ ) consists of 315 students, who were reached with convenience sampling method, and a $95 \%$ confidence interval has been used with an error margin of $5 \%$.

\subsection{Measurement Instrument}

The data were collected with the 4-point Likert-type and 10-item "Self-Esteem Scale," developed by Rosenberg (1965) and adapted to Turkish by Çuhadaroğlu (1986) and the 5-point Likert-type "Leadership Orientation Scale," developed by Luthans (1995) and adapted to Turkish by Dereli (2003) which has 2 subscales, task-oriented and relationship-oriented. The factor loadings of the self-esteem scale were found to be between (0.789) and (0.421) and 
the KMO value was found to be (0.833). The factor loads of the leadership orientation scale were found to be between 0.883 and 0.371 and the KMO value was found to be (0.784). The internal consistency reliability analysis $(\alpha=0.91)$ of the Rosenberg Self-Esteem scale among the items was found to be $(\alpha=0.80)$. The internal consistency reliability analysis of the leadership orientation scale among the items was found to be $(\alpha=0.80)$ for task-oriented sub-scale, it was found to be $(\alpha=0.62)$ for the relationship-oriented sub-scale, and it was found to be $(\alpha=0.84)$ for leadership orientation in general. According to these results, it can be stated that the internal consistency reliability between the items of the data collection tools used in the study is high.

\subsection{Statistical Analysis}

Since the data was found to have a normal distribution after the analysis, the correlation analysis has been used to identify the relationship between the two continuous variables and regression analysis has been used to measure the effect.

Table-1. Descriptive statistics regarding the students.

\begin{tabular}{l|c|c|c}
\hline Variables & Groups & $\mathbf{f}$ & $\mathbf{\%}$ \\
\hline \multirow{2}{*}{ Gender } & Female & 184 & 58.4 \\
\cline { 2 - 4 } & Male & 131 & 41.6 \\
\hline \multirow{2}{*}{ Age } & $18-20$ & 186 & 59 \\
\cline { 2 - 4 } Practicing sports with a license or not & $21-24$ & 129 & 41 \\
\cline { 2 - 4 } & Yes & 210 & 66.7 \\
\cline { 2 - 4 } Note: $\mathrm{n}=315$. & No & 105 & 33.3 \\
\hline
\end{tabular}

As seen in Table 1, $58.4 \%$ of the students are women, $41.6 \%$ are men, $59 \%$ are between the ages of $18-20,41 \%$ are between the ages of $21-24,66.7 \%$ practice sports with a license, and $33.3 \%$ do not practice sports with a license.

Table-2. Normality analysis of the data.

\begin{tabular}{l|c|c|c|c|c|c}
\hline Scales and Sub-dimensions & $\overline{\boldsymbol{x}}$ & median & variance & sd & skewness & kurtosis \\
\hline Self-Esteem & 21.32 & 22 & 32.15 & 5.67 & 0.083 & -0.554 \\
\hline Leadership Orientation & 86.30 & 87 & 176.72 & 13.29 & -0.177 & -0.335 \\
\hline Task-Oriented & 48.24 & 48.00 & 75.30 & 8.68 & -0.047 & -0.406 \\
\hline Relationship-Oriented & 36.50 & 36.00 & 35.40 & 5.95 & -0.076 & -0.238 \\
\hline
\end{tabular}

Note: $\mathrm{n}=315$

As seen in Table 2, when the values of the scales and sub-dimensions are examined, the average and median values are close to each other, the skewness and kurtosis values are between \pm 1.96 (Büyüköztürk, 2016) and according to this result, the data has a normal distribution, so parametric analyses have been carried out.

\begin{tabular}{|c|c|c|c|c|c|}
\hline Scales and Sub-dimensions & $\mathbf{n}$ & Minimum & Maximum & $\bar{x}$ & sd \\
\hline Self-Esteem & 315 & 10 & 35 & 21.32 & 5.67 \\
\hline Leadership Orientation & 315 & 48 & 118 & 86.30 & 13.25 \\
\hline
\end{tabular}

As seen in Table 3, it was found that the self-esteem $(\bar{x}=21.32)$ and leadership orientation $(\bar{x}=86.30)$ levels of the students are high.

\section{Findings}

Table-4. Regression analysis of the scales and sub-dimensions.

\begin{tabular}{|c|c|c|c|c|}
\hline Scales and Sub-dimensions & 1 & 2 & 3 & 4 \\
\hline 1 - Self-Esteem & 1 & & & \\
\hline \multirow{2}{*}{2 - Leadership Orientation } & $171 * *$ & \multirow{2}{*}{1} & & \\
\hline & 0.002 & & & \\
\hline \multirow{2}{*}{3 - Task-Oriented } & $186^{* *}$ & $0.950^{* * *}$ & \multirow{2}{*}{1} & \\
\hline & 0.001 & 0.000 & & \\
\hline \multirow{2}{*}{4 - Relationship-Oriented } & $0.141^{*}$ & $0.783 * *$ & $0.672^{* *}$ & \multirow{2}{*}{1} \\
\hline & 0.012 & 0.000 & 0.000 & \\
\hline
\end{tabular}

As can be seen in Table 4, there is a significantly low level of relationship between the self-esteem levels of the students and their leader orientation and its sub-dimensions, task-oriented and relationship-oriented leadership.

\begin{tabular}{|c|c|c|c|c|c|c|c|}
\hline \multirow{2}{*}{$\begin{array}{l}\text { Independent } \\
\text { Variable }\end{array}$} & \multicolumn{2}{|c|}{ Unstandardized Coefficients } & \multicolumn{3}{|c|}{ Standardized Coefficients } & \multicolumn{2}{|c|}{ Collinearity Statistics } \\
\hline & B & SH & $\boldsymbol{\beta}$ & $\mathbf{t}$ & $p$ & Tolerance & VIF \\
\hline Constant & 77.75 & 2.88 & & 27.000 & 0.000 & \multirow{2}{*}{1.000} & \multirow{2}{*}{1.000} \\
\hline Self-Esteem & 0.401 & 0.131 & 0.171 & 3.074 & $0.002 *$ & & \\
\hline \multicolumn{3}{|c|}{\begin{tabular}{|l|l}
$\mathrm{R}^{2}=.029 ; \mathrm{R}=.171$ & \\
\end{tabular}} & & & & & \\
\hline \multicolumn{3}{|c|}{$\mathrm{F}_{(1-313)}=9.447 ; \mathrm{p}=0.002 ;$ Durbin Watson $=1.906$} & & & & & \\
\hline
\end{tabular}

Note: Dependent Variable: Leadership Orientation; Unstandardized coefficients are used. 
As seen in Table 5, the impact analysis of the self-esteem levels of the students on their leadership orientations is significant $\left(\mathrm{F}_{(1-313)}=9.447 ; \mathrm{p}=0.002\right)$. It was found that the self-esteem levels of the students explain $2.9 \%$ of their leadership orientation $\left(\mathrm{R}^{2}=.029\right)$. As a result of the analysis, it was found that the self-esteem levels of the students have a significant positive effect on their leadership orientation $(\beta=.40)$.

Table-6. Impact analysis of the self-esteem levels of the students on task-oriented leadership sub-dimension.

\begin{tabular}{l|c|c|c|c|c|c|c}
\hline \multirow{2}{*}{ Independent Variable } & Unstandardized Coefficients & Standardized Coefficients & \multicolumn{2}{c}{ Collinearity Statistics } \\
\cline { 2 - 7 } & $\mathbf{B}$ & $\mathbf{S H}$ & $\boldsymbol{\beta}$ & $\mathbf{t}$ & $\boldsymbol{p}$ & Tolerance & VIF \\
\hline Constant & 42.83 & 1.87 & & 22.502 & 0.000 & \multirow{2}{*}{1.000} \\
\hline Self-Esteem & 0.284 & 0.85 & 0.186 & 3.345 & $0.001^{*}$ & \\
\hline $\mathrm{R}^{2}=.035 ; \mathrm{R}=.186$ & & & & & & \\
\hline $\mathrm{F}_{(1-313)}=11.190 ; \mathrm{p}=0.001 ;$ Durbin Watson=1.004 & & & & & \\
\hline
\end{tabular}

Note: Dependent Variable: Task-Oriented Leadership; Unstandardized coefficients are used.

As seen in Table 6, the impact analysis of the self-esteem levels of the students on the task-oriented leadership sub-dimension is significant $\left(\mathrm{F}_{(1-313)}=11.190 ; \mathrm{p}=0.001\right)$. It was found that self-esteem levels of the students explain $3.5 \%$ of their leadership orientation $\left(\mathrm{R}^{2}=.035\right)$. As a result of the analysis, it was found that the self-esteem levels of the students have a significant positive effect on task-oriented leadership $(\beta=.28)$.

Table-7. Impact analysis of the self-esteem levels of the students on relationship-oriented leadership sub-dimension

\begin{tabular}{l|c|c|c|c|c|c|c}
\hline \multirow{2}{*}{ Independent Variable } & \multicolumn{2}{|c|}{ Unstandardized Coefficients } & \multicolumn{2}{c|}{ Standardized Coefficients } & \multicolumn{2}{c}{ Collinearity Statistics } \\
\cline { 2 - 7 } & $\mathbf{B}$ & $\mathbf{S H}$ & $\boldsymbol{\beta}$ & $\mathbf{t}$ & $\boldsymbol{p}$ & Tolerance & VIF \\
\hline Constant & 33.34 & 1.29 & & 22.744 & 0.000 & \multirow{2}{*}{1.000} \\
\hline Self-Esteem & 0.148 & 0.59 & 0.141 & 2.522 & $0.012^{*}$ & \\
\hline $\mathrm{R}^{2}=.020 ; \mathrm{R}=.141$ & & & & & & \\
\hline $\mathrm{F}_{(1-313)}=6.361 ; \mathrm{p}=0.012 ;$ Durbin Watson $=1.238$ & & & & & \\
\hline
\end{tabular}

Note: Dependent Variable: Relationship-Oriented Leadership; Unstandardized coefficients are used.

As seen in Table 7, the impact analysis of the effect of self-esteem levels of the students on relationshiporiented leadership subscale levels is significant $\left(\mathrm{F}_{(1-313)}=6.361 ; \mathrm{p}=0.012\right)$. It was found that the self-esteem levels of the students explain $2 \%$ of their leadership orientation $\left(\mathrm{R}^{2}=.020\right)$. As a result of the analysis, it was found that the self-esteem levels of the students have a significant positive effect on their relationship-oriented leadership $(\beta=.14)$.

\section{Discussion}

In this study, in which the effect of the self-esteem levels of students studying at sports management departments of faculty of sports sciences on the leadership orientation has been examined, and it can be stated that the students who participated in the study have high self-esteem levels and leadership tendencies in general (Table 3). According to this result, it can be stated that students with a high level of self-esteem also have a high level of energy and vitality, they are self-confident, in peace with themselves, and emotionally stable. Studies on self-esteem levels have been found in the literature. In the study conducted by Topuz, Bahadir, and Erdogan (2019) it was found that the self-esteem levels of the students who receive education in sports management are moderate. In another study (Armstrong \& Oomen-Early, 2009; Tremblay, Inman, \& Willms, 2000) it can be said that athletes have higher self-esteem levels than non-athletes, so they are more self-confident, vigorous, energetic, and extroverted. In our study, it was observed that there is a significant and positive relationship between the selfesteem levels of the students studying at sports management department of a sports science faculty and taskoriented leadership and relationship-oriented leadership. According to this result, it was concluded that as the selfesteem levels of the students increase, their self-confidence increase accordingly, and as their beliefs about achievement increase, their leadership orientation, task-oriented and relationship-oriented behavior increase as well. In our study, it was observed that the self-esteem levels of the students have a significant effect on their leadership orientation. According to this result, it can be stated that high self-esteem affects leadership orientations and these students have leadership qualities (Table 5). The self-esteem levels of the students were found to have a significant and positive effect on task-oriented leadership (Table 6) and relationship-oriented leadership (Table 7), which are sub-dimensions of leadership orientation. According to this result, the effect of the self-esteem levels of the students on their task-related leadership styles consists of students who are able to give detailed and direct instructions, who closely follow the task they assign, and who are in favor of supervision for management. It can be stated that the self-esteem levels of the students affect their relationship-related leadership styles, it consists of students who care about their subordinates, respect their opinions and thoughts, protect their rights and interests, and take responsibility for their mistakes when necessary. Although the number of studies that examine the effect of self-esteem on leadership orientation are quite limited in the literature, there are also studies that are similar to the results of our study in some respects. Li, Arvey, and Song (2011) found that individuals' self-esteem has a significant and positive effect on their leadership styles and their progress in leadership. In the study conducted by Akdeniz and Saytekin (2020) a high level of positive relationship was found between inner self-esteem and leadership orientation of sports science students. According to this result, students who have high internal selfesteem also have high level of orientation and qualifications towards being leaders. In the doctoral dissertation written by (Moran, 2015) it was found that self-esteem levels of students have a significant effect on leadership behaviors. It can be stated that students' self-esteem, self-confidence, and high level of success also increase their leadership behavior and tendency towards leadership. 


\section{Conclusion}

In this study, which has been carried out to examine the effect of self-esteem levels of the students who receive sports management education on their leadership orientation and task-oriented and relationship-oriented leadership orientation, it has been observed that these students have high levels of self-esteem and leadership orientation in general. It is considered that the fact that self-esteem levels of the students have a significant effect on their leadership orientation, task-oriented and relationship-oriented leadership will increase their commitment to the task and they will have a high level of success, and they will be management-oriented. It can also be stated that they will treat their subordinates democratically, consult them when making decisions, adopt a leadership style that values, protects, and defends their opinions and thoughts.

\section{References}

Akdeniz, H., \& Saytekin, G. N. (2020). Examination of leadership orientations and self-confidence behaviors of faculty of sport sciences students (Kocaeli University Sample). International Journal of Curriculum and Instruction, 12, 233-250.

Amanchukwu, R. N., Stanley, G. J., \& Ololube, N. P. (2015). A review of leadership theories, principles and styles and their relevance to educational management. Management, 5(1), 6-14.

Armstrong, S., \& Oomen-Early, J. (2009). Social connectedness, self-esteem, and depression symptomatology among collegiate athletes versus nonathletes. Journal of American College Health, 57(5), 52 1-526.Available at: https://doi.org/10.3200/jach.57.5.52 1-526.

Burger, J. M. (2006). Personality. Translated by, İnan Deniz, Erguvan Sarıŏ lu. İstanbul: Kaknüs Publishing.

Büyüköztürk, Ş. (2016). Data analysis handbook (22nd ed.). Ankara: Pegem Academy Publishing House.

Çiçekler, C., \& Pirpir, A. D. (2015). Investigation of child rearing behaviors of mothers with children between months and self concepts of children. Hacettepe University Faculty of Health Sciences Journal, 1(2), 491-500.

Cooley, C. H. (1902). Human nature and the social order. New York: Charles Scribner and Sons.

Coopersmith, S. (1981). The anticedents of self-esteem. Palo Alto: Consulting Psychologists Pres,Inc.

Correa, J. A. A., Morales, G., \& Pozo, E. C. (2005). Leadership and organizational learnings role on innovation and performance: Lessons from Spain. Industrial Marketing Management, 7(1), 1-11.

Çuhadaroğlu, F. (1986). Self-Esteem in adolescents, hacettepe university faculty of medicine. Department of Psychiatry Unpublished Thesis, Ankara.

Dereli, M. (2003). A survey research of leadership styles of elementary school principlas. Master Thesis, Middle East Technical University, Institute of Social Sciences, Ankara.

Geva, D., \& Torpey, J. (2008). Citizenship and military service: Questioning the link in a post-heroic age. Paper presented at the Annual Meeting of the American Sociological Association, Sheraton Boston and the Boston Marriott Copley Place, Boston, MA, 31 July.

Gürbüz, S., \& Şahin, F. (2018). Research methods in social sciences (5th ed.). Ankara: Seckin Publishing.

Harris, A. (2009). Distributed leadership. London: Springer.

Harry, A. (2002). Think like a leader, Translated by Halime Misge Kurşun (1 st ed.). İstanbul: Kariyer Publishing.

House, R. J., \& Aditya, R. N. (1997). The social scientific study of leadership: Quo vadis? Journal of Management, 23(3), 409-473.Available at: https://doi.org/10.1177/014920639702300306.

Imbroda-Ortiz, J., Castillo-Rodríguez, A., \& Minguet, J. (2015). Sports management, leadership in the organization. Journal of Physical Education and Sports Management, 2(2), 56-65.Available at: https://doi.org/10.15640/jpesm.v2n2a5.

James, W. (1892). Psychology: The briefer course. New York: Henry Holt.

Kernis, M. H. (2003). Target: Article: Toward a conceptualization of optimal self- esteem. Psychological Injury, 14(1), 1-26.

Li, W.-D., Arvey, R. D., \& Song, Z. (2011). The influence of general mental ability, self-esteem and family socioeconomic status on leadership role occupancy and leader advancement: The moderating role of gender. The Leadership Quarterly, 22(3), 520-534.Available at: https://doi.org/10.1016/j.leaqua.2011.04.009.

Luthans, F. (1995). Organizational behavior (5th ed.): Mc Graw Hill.

Mason, C., Mason, K., \& Mathews, A. (2016). Aspiring to lead: An investigation into the interactions between self-esteem, patriarchal attitudes, gender, and Christian leadership. Journal of Psychology and Theology, 44(3), 244-256.Available at: https://doi.org/10.1177/009164711604400306.

Moran, A. J. (2015). An examination of self-esteem's impact on the leadership behaviors offemale undergraduate student leaders. Master Theses.

Morganett, S. R. (2005). Life skills, Translated by, Sonay Güçray, Alim Kaya, Mesut Saçkes. Istanbul: Pegem Publishing.

Orth, U., \& Robins, R. W. (2014). The development of self-esteem. Current Psychological Science, 23(5), 381-387.

Plummer, D. (2005 ). Helping adolescent and adult to build self-Esteem. London: Jessica Kingsley Publisher.

Rosenberg, M. (1965). Rosenberg self-esteem scale (RSE). Acceptance and commitment therapy. Measures Package, $61(52), 18$.

Sayar, K. (2003). Benlik: O Yakın Soru, O Uzak Ülke. Bilge Adam, 1, 11-17.

Suar, D., Tewari, H. R., \& Chaturbedi, K. R. (2006). Subordinates' perception of leadership styles and their work behaviour. Psychology and Developing Societies, 18(1), 95-114.Available at: https://doi.org/10.1177/097133360501800106.

Topaloğlu, C., \& Avcı, U. (2008). Causes and management of conflict: A review from the managerial perspective in hotel businesses. Süleyman Demirel University the Journal of Faculty of Economics and Administrative Sciences, 13(2), 75-92.

Topuz, R., Bahadir, Z., \& Erdogan, Ç. H. (2019). Examining the social appearance anxiety and self-esteem levels of students of the sport management department. Asian Journal of Education and Training, 5(1), 74-79.

Tremblay, M. S., Inman, J. W., \& Willms, J. D. (2000). The relationship between physical activity, self-esteem, and academic achievement in 12-year-old children. Pediatric Exercise Science, 12(3), 312-323.Available at: https://doi.org/10.1123/pes.12.3.312.

Woolfolk, A., \& Shaughnessy, M. F. (2004). An interview with Anita Woolfolk: The educational psychology of teacher efficacy. Educational Psychology Review, 16(2), 153-176.

Yörükoğlu, A. (2000). Touth age mental health and mental problems (1 1 th ed.). Istanbul: Özgür Publishing. 